\title{
Text Segmentation for Analysing Different Languages
}

\author{
Irina $\mathrm{Pak}^{1}$, Phoey Lee $\mathrm{Teh}^{2}$ \\ \{irina.p@imail.sunway.edu.my ${ }^{1}$, phoeyleet@sunway.edu.my ${ }^{2}$ \} \\ Department of Computing and Information Systems, \\ Sunway University, Bandar Sunway, Malaysia ${ }^{1,2}$
}

\begin{abstract}
Over the past several years, researchers have applied different methods of text segmentation. Text segmentation is defined as a method of splitting a document into smaller segments, assuming with its own relevant meaning. Those segments can be classified into the tag, word, sentence, topic, phrase and any information unit. Firstly, this study reviews the different types of text segmentation methods used in different types of documentation, and later discusses the various reasons for utilising it in opinion mining. The main contribution of this study includes a summarisation of research papers from the past 10 years that applied text segmentation as their main approach in text analysing. Results show that word segmentation was successfully and widely used for processing different languages.
\end{abstract}

Keywords: Text Segmentation, Text Analysis, Text Processing, Languages, Online Reviews, Opinion Mining.

\section{Introduction}

Segmentation is splitting a document into segments. The segment is also referred as "segment boundary" [1] or passage [2]. While another studies referred segment as subtopic [3] and region of interest [4]. There are many reasons why the splitting document can be useful for text analysis. One of the main reasons is handling those segments is easier since they are smaller and more coherent than whole documents [2]. Another reason is segments can be used as units of analysis and access [2]. Text segmentation was used to process text in opinion mining [5] [6], information retrieval [7], emotion extraction [8], sentiment mining [9] [10] and language detection [11].

This paper reviews different methods and reasons of applying text segmentation in opinion and sentiment mining, language detection and information retrieval. The target of this survey is to give an overview of text segmentation techniques with brief details. The contribution of this paper includes the categorizations of recent articles and the illustration of the recent trend of research in the opinion mining and related areas like sentiment analysis and emotion detection.

Section 2 of this paper explains the method used to review the past studies. Section 3 discusses the results of summarised articles. Section 4 concludes this paper. 


\section{Review Method}

This paper is limited to thirty articles which are summarised in Table 1. It includes a summarization of past 10 years of articles from journals and conferences that involved text segmentation as their approaches. The first column contains the references [12-35] of the articles. The second column contains the year of the evaluated study. Following column briefly, describes the evaluated study. The fourth column states the type of segment used in the evaluated study. The segmentation is used for different types of document, column five contains information regarding the type of documents. The reasons for applying segmentation in particular studies are stated in the following column. The last column shows the type of language in tested documents.

\section{Results}

Table 1. Summarisation of articles.

\begin{tabular}{|c|c|c|c|c|c|}
\hline $\begin{array}{l}\text { RefeYear } \\
\text { renc } \\
\text { es }\end{array}$ & Description & $\begin{array}{l}\text { Type of } \\
\text { segment }\end{array}$ & $\begin{array}{l}\text { Type of } \\
\text { documents }\end{array}$ & Reason & Language \\
\hline [12] 2006 & $\begin{array}{l}\text { Improving text } \\
\text { segmentation using } \\
\text { latent semantic analysis }\end{array}$ & Sentence & Corpus & $\begin{array}{l}\text { To improve the } \\
\text { accuracy of } \\
\text { segmentation }\end{array}$ & $\begin{array}{l}\text { Belgian } \\
\text { French }\end{array}$ \\
\hline [5] 2006 & $\begin{array}{l}\text { Automatic text } \\
\text { summarization for } \\
\text { dialogue style }\end{array}$ & Text block & $\begin{array}{l}\text { Dialogue } \\
\text { samples } \\
\text { Corpus }\end{array}$ & $\begin{array}{l}\text { To identify dialogue } \\
\text { content }\end{array}$ & Chinese \\
\hline [13] 2006 & $\begin{array}{l}\text { HTML text } \\
\text { segmentation for Web } \\
\text { page summarization }\end{array}$ & Sentence & Web pages & $\begin{array}{l}\text { To identify Web } \\
\text { page content }\end{array}$ & Japanese \\
\hline [6] 2007 & $\begin{array}{l}\text { Opinion search in web } \\
\text { blogs (logs) }\end{array}$ & Topic & Web blog & $\begin{array}{l}\text { To identify opinion } \\
\text { in web blogs }(\operatorname{logs})\end{array}$ & English \\
\hline [8] 2007 & $\begin{array}{l}\text { Comprehensive } \\
\text { information based } \\
\text { semantic orientation } \\
\text { identification }\end{array}$ & Word & Comments & $\begin{array}{l}\text { To identify polarity } \\
\text { orientation in text }\end{array}$ & Chinese \\
\hline [14] 2008 & $\begin{array}{l}\text { Automatic Story } \\
\text { Segmentation in } \\
\text { Chinese Broadcast } \\
\text { News }\end{array}$ & Topic & News & $\begin{array}{l}\text { To identify story } \\
\text { boundary }\end{array}$ & Chinese \\
\hline [15] 2009 & $\begin{array}{l}\text { Aspect-based sentence } \\
\text { segmentation for } \\
\text { sentiment } \\
\text { summarization }\end{array}$ & Sentence & Reviews & $\begin{array}{l}\text { To extract aspect- } \\
\text { based sentiment } \\
\text { summary }\end{array}$ & Chinese \\
\hline [16] 2009 & $\begin{array}{l}\text { Chinese text sentiment } \\
\text { classification }\end{array}$ & Word & Corpus & $\begin{array}{l}\text { To classify text } \\
\text { based on sentiment } \\
\text { value }\end{array}$ & Chinese \\
\hline
\end{tabular}




\begin{tabular}{|c|c|c|c|c|c|}
\hline [17] 2010 & $\begin{array}{l}\text { An information- } \\
\text { extraction system for } \\
\text { Urdu-a resource-poor } \\
\text { language }\end{array}$ & Word & $\begin{array}{l}\text { Blogs, } \\
\text { comments, } \\
\text { news } \\
\text { articles }\end{array}$ & $\begin{array}{l}\text { To identify social } \\
\text { and human } \\
\text { behaviour within } \\
\text { text }\end{array}$ & Urdu \\
\hline [9] 2010 & $\begin{array}{l}\text { Sentiment } \\
\text { classification for stock } \\
\text { news }\end{array}$ & Word & $\begin{array}{l}\text { Chinese } \\
\text { stock news }\end{array}$ & $\begin{array}{l}\text { To classify news by } \\
\text { sentiment orientation }\end{array}$ & Chinese \\
\hline [10] 2010 & $\begin{array}{l}\text { Sentiment text } \\
\text { classification of } \\
\text { customers } \\
\text { reviews on the web } \\
\text { based on SVM }\end{array}$ & Word & Comments & $\begin{array}{l}\text { To improve accuracy } \\
\text { of sentiment } \\
\text { classification }\end{array}$ & Chinese \\
\hline [18] 2010 & $\begin{array}{l}\text { The application of text } \\
\text { mining technology in } \\
\text { monitoring the network } \\
\text { education public } \\
\text { sentiment }\end{array}$ & Word & $\begin{array}{l}\text { Web } \\
\text { documents }\end{array}$ & $\begin{array}{l}\text { To analyse sentiment } \\
\text { in text to monitor } \\
\text { public network }\end{array}$ & tChinese \\
\hline [19] 2010 & $\begin{array}{l}\text { Using text mining and } \\
\text { sentiment analysis for } \\
\text { online forums hotspot } \\
\text { detection and forecast }\end{array}$ & Word & Forums & $\begin{array}{l}\text { To design a text } \\
\text { sentiment approach }\end{array}$ & Chinese \\
\hline [20] 2011 & $\begin{array}{l}\text { A topic modelling } \\
\text { perspective for text } \\
\text { segmentation. }\end{array}$ & Topic & Corpus & $\begin{array}{l}\text { To design an } \\
\text { enhanced topic } \\
\text { extraction approach }\end{array}$ & English \\
\hline [21] 2011 & $\begin{array}{l}\text { Text segmentation of } \\
\text { consumer magazines in } \\
\text { PDF format }\end{array}$ & Text block & $\begin{array}{l}\text { s Articles in } \\
\text { PDF } \\
\text { documents }\end{array}$ & $\begin{array}{l}\text { To process PDF } \\
\text { documents }\end{array}$ & English \\
\hline [22] 2011 & $\begin{array}{l}\text { Rule-based Malay text } \\
\text { segmentation tool }\end{array}$ & Sentence & Articles & $\begin{array}{l}\text { To design Malay } \\
\text { sentence } \\
\text { splitter and tokenizer }\end{array}$ & $\begin{array}{l}\text { Malay } \\
\text { English }\end{array}$ \\
\hline [23] 2012 & $\begin{array}{l}\text { Usage of text } \\
\text { segmentation } \\
\text { and inter-passage } \\
\text { similarities }\end{array}$ & Passages & Articles & $\begin{array}{l}\text { To improve text } \\
\text { document clustering }\end{array}$ & English \\
\hline [24] 2012 & $\begin{array}{l}\text { Two-part segmentation } \\
\text { of text documents }\end{array}$ & $\begin{array}{l}\text { Word } \\
\text { Sentence }\end{array}$ & Corpus & $\begin{array}{l}\text { To process problem } \\
\text { and solution } \\
\text { documents }\end{array}$ & English \\
\hline [25] 2012 & $\begin{array}{l}\text { Text line segmentation } \\
\text { in historical documents }\end{array}$ & Line & $\begin{array}{l}\text { Historical } \\
\text { documents }\end{array}$ & $\begin{array}{l}\text { To combine } \\
\text { the strengths of top- } \\
\text { down and bottom-up } \\
\text { approaches }\end{array}$ & Ancient \\
\hline [26] 2012 & $\begin{array}{l}\text { Topic segmentation of } \\
\text { Chinese text based on } \\
\text { lexical chain }\end{array}$ & Topic & News & $\begin{array}{l}\text { To improve method } \\
\text { of processing text }\end{array}$ & Chinese \\
\hline [27] 2013 & $\begin{array}{l}\text { Semantic-based text } \\
\text { block segmentation }\end{array}$ & \multicolumn{2}{|c|}{ Text blocks Web page } & $\begin{array}{l}\text { To retrieve image } \\
\text { based on text around } \\
\text { it }\end{array}$ & English \\
\hline
\end{tabular}




\begin{tabular}{|c|c|c|c|c|c|}
\hline [28] 2013 & $\begin{array}{l}\text { Segmentation system } \\
\text { based on the } \\
\text { sentiments expressed in } \\
\text { the text. }\end{array}$ & $\begin{array}{l}\text { Tag } \\
\text { Word }\end{array}$ & Reviews & $\begin{array}{l}\text { To design system } \\
\text { which identifies a } \\
\text { sentiment expressed } \\
\text { in text/ }\end{array}$ & English \\
\hline [11] 2014 & $\begin{array}{l}\text { Recognition-based } \\
\text { segmentation of online } \\
\text { Arabic text recognition }\end{array}$ & Word & Dataset & $\begin{array}{l}\text { To recognise Arabic } \\
\text { text within } \\
\text { handwriting }\end{array}$ & Arabic \\
\hline [29] 2014 & $\begin{array}{l}\text { Text segmentation for } \\
\text { language identification } \\
\text { in Greek forums }\end{array}$ & $\begin{array}{l}\text { Sentence } \\
\text { Topic }\end{array}$ & Forums & To identify language & $\begin{array}{l}\text { Greek } \\
\text { English }\end{array}$ \\
\hline [30] 2015 & $\begin{array}{l}\text { Chinese text sentiment } \\
\text { orientation } \\
\text { identification }\end{array}$ & Character & Corpus & $\begin{array}{l}\text { To identify } \\
\text { sentiment in the text }\end{array}$ & Chinese \\
\hline [31] 2015 & $\begin{array}{l}\text { Text segmentation } \\
\text { based on Semantic } \\
\text { word embedding }\end{array}$ & Word & Articles & $\begin{array}{l}\text { To enhance semantic } \\
\text { word embedding } \\
\text { approach }\end{array}$ & English \\
\hline [32] 2015 & $\begin{array}{l}\text { A multi-label } \\
\text { classification based } \\
\text { approach for sentiment } \\
\text { classification }\end{array}$ & Word & Microblogs & $\begin{array}{l}\text { To support a } \\
\text { sentiment } \\
\text { classification } \\
\text { approach }\end{array}$ & Chinese \\
\hline [33] 2016 & $\begin{array}{l}\text { Vietnamese word } \\
\text { segmentation }\end{array}$ & Word & Dictionaries & $\begin{array}{l}\text { sTo check how } \\
\text { dictionary size } \\
\text { affects word } \\
\text { segmentation }\end{array}$ & Vietnamese \\
\hline [34] 2016 & $\begin{array}{l}\text { Phrase-level } \\
\text { segmentation and } \\
\text { labelling }\end{array}$ & Phrase & Dataset & $\begin{array}{l}\text { To balance between } \\
\text { the word and } \\
\text { sentence levels }\end{array}$ & English \\
\hline [35] 2016 & $\begin{array}{l}\text { Akkadian word } \\
\text { segmentation }\end{array}$ & Word & Corpora & $\begin{array}{l}\text { To improve the } \\
\text { language processing } \\
\text { in cuneiform }\end{array}$ & $\begin{array}{l}\text { Ancient } \\
\text { Akkadian }\end{array}$ \\
\hline
\end{tabular}

Table 1 presents the summarisation for the review of past years' studies. Different types of segmentation are discussed. For instance, topic segmentation has been successfully applied in tackling the problem of information overload that occur when the whole document is presented at once. Misra et al. [20] stated the reason behind splitting document can be reasonable to present only the relevant part(s) of a document, because presenting the whole document without segmentation may result in information overload. Paliwal and Pudi [23] addressed the same problem. Which led them to propose a clustering approach based on topic segmentation. Topic segmentation is popular in opinion mining area. For instance, studies of [20] [6] [26] used the topic as a segment. 


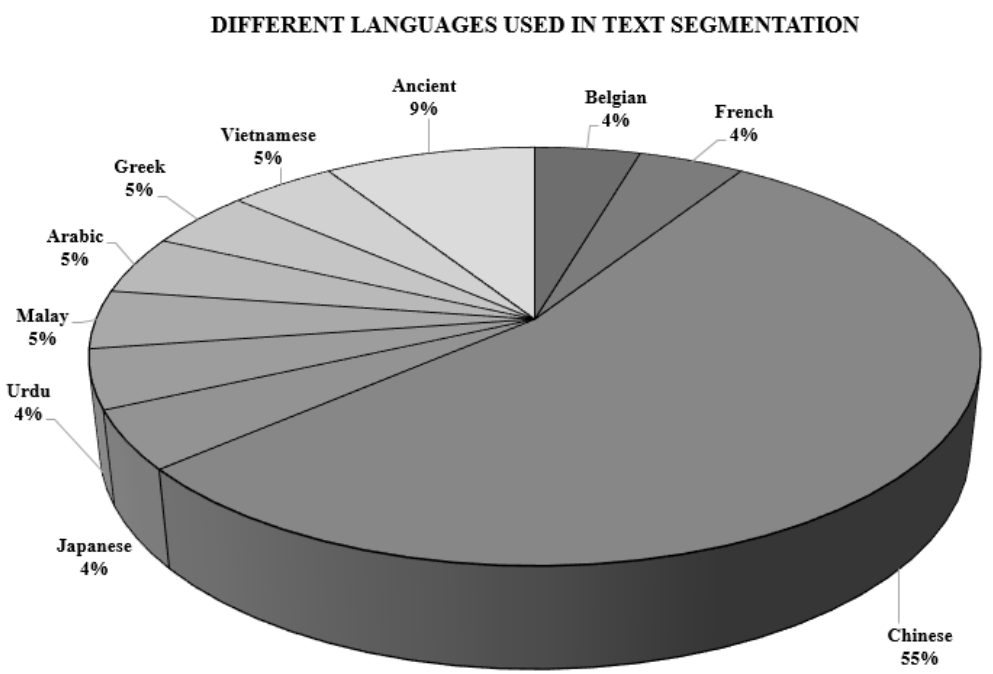

Fig. 1. Percentage of different languages used for text segmentation.

Another type of segmentation is word segmentation, Homburg and Chiarcos [35] describe word segmentation as the most elementary task in natural language processing of written language. This type of segmentation was applied in language detection. Figure 1 illustrates the numbers of percentage for each language beside English used in evaluated studies. For instance, studies of [5] [8] [9] [10] [16] [18] [19] [30] [32] used word (character) segmentation for analysing Chinese text. Beside the Chinese language, there are studies which applied word segmentation for Urdu[17], Arabic [11], Vietnamese [33], and Akkadian [35]. However, other studies [13][29][22] applied sentence segmentation to analyse Japanese, Greek and Malay languages accordingly. As it is seen, there is a trend to apply text segmentation in the analysing text in different languages. 


\section{TYPES OF SEGMENT USED FOR DIFFERENT DOCUMENTS}

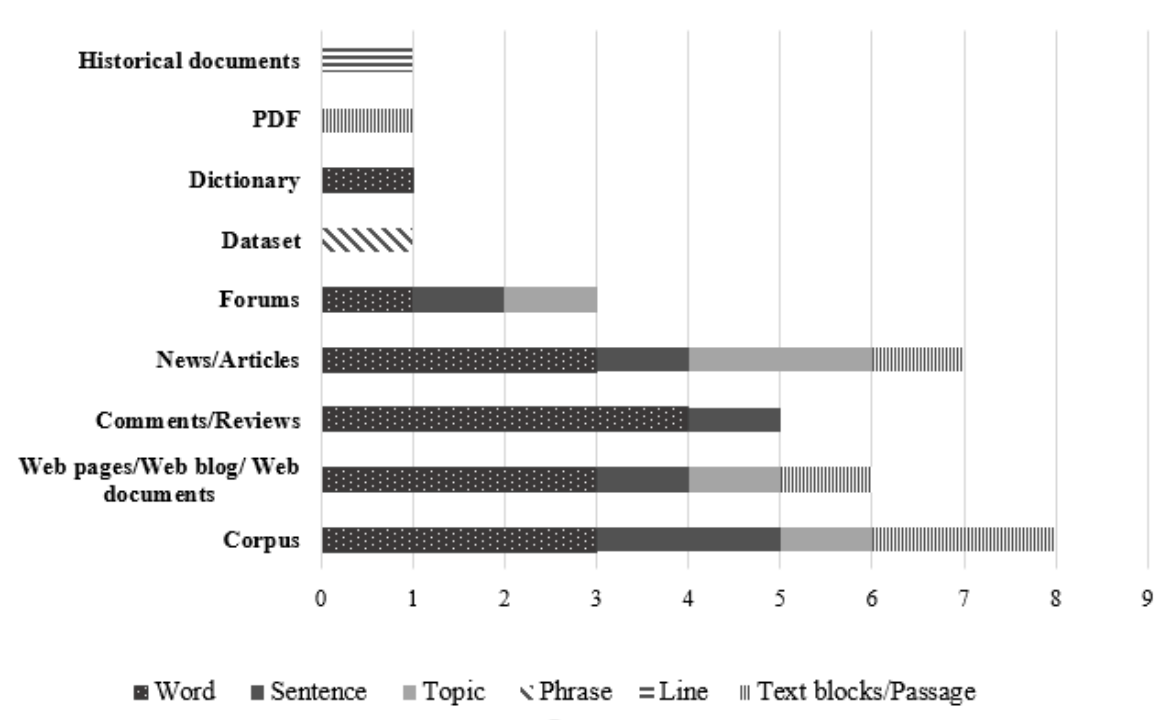

Fig. 2. Chart of different types of segments used for different types of document.

Different types of the document and datasets were used in research experiments in order to check text segmentation accuracy. Figure 2 presents a number of each type of segments used for different types of document derived from Table 1. In this study, web pages, web blog and web documents are categorised as one group. By comparison, it is the most used type of document referring to the Figure 2. After web pages, web blog and web documents, the second widely used type of document is comments and reviews. Segments can be classified into the tag, word, sentence, topic, phrase and any information unit. Figure 2 concludes that word is the most used type of segment.

As a result, we noticed the trend of applying text and sentence segmentation in processing and analysing different languages such as Chines, Vietnamese, Urdu, Arabic, and Ancient languages. Besides applying text segmentation for different languages, text segmentation successfully applied in opinion mining for news, blog and stock market. Finally, word segment is the most used compare to another types of the segment. The reason can be an as smaller segment to process as more detailed analysis can be done.

\section{Conclusion}

This paper presents an overview of the text segmentation methods and reasons in text processing and analysing. Thirty published articles for past 10 years were categorised and summarised. Those articles give contributions to text processing in information retrieval, emotion extraction, sentiment mining and language detection.

Results show that word as the segment is the most used compare to other types of the segment. It means that processing smaller segments can be more useful and meaningful for deeper and more detailed analysing of the text. Different types of document are used as a 
dataset for the experiment. The most popular are web pages, web blog and web document following by comments and reviews. That indicates that information from the online users and consumers plays an important role in expressing people's emotions, opinions and feelings.

\section{References}

[1] Scaiano M, Inkpen D, Laganière R, Reinhartz A (2010) Automatic text segmentation for movie subtitles. In: Lect. Notes Comput. Sci. Springer, pp 295-298

[2] Oh H, Myaeng SH, Jang M-G (2007) Semantic passage segmentation based on sentence topics for question answering. Inf Sci (Ny) 177:3696-3717.

[3] Song F, Darling WM, Duric A, Kroon FW (2011) An Iterative Approach to Text Segmentation. In: 33rd Eur. Conf. IR Res. 2011. Springer Berlin Heidelberg, Dublin, pp 629-640

[4] Oyedotun OK, Khashman A (2016) Document segmentation using textural features summarization and feedforward neural network. Appl Intell 45:1-15.

[5] Liu C, Wang Y, Zheng F (2006) Automatic text summarization for dialogue style. In: Proc. IEEE ICIA 2006 - 2006 IEEE Int. Conf. Inf. Acquis. IEEE, Weihai, pp 274-278

[6] Osman DJ, Yearwood JL (2007) Opinion search in web logs. Conf Res Pract Inf Technol Ser 63:133-139.

[7] Huang X, Peng F, Schuurmans D, et al (2003) Applying Machine Learning to Text Segmentation. Inf Retr J 6:333-362.

[8] Wu Y, Zhang Y, Luo SM, Wang XJ (2007) Comprehensive information based semantic orientation identification. In: IEEE NLP-KE 2007 - Proc. Int. Conf. Nat. Lang. Process. Knowl. Eng. IEEE, Beijing, pp 274-279

[9] Gao Y, Zhou L, Zhang Y, et al (2010) Sentiment classification for stock news. In: ICPCA10 5th Int. Conf. Pervasive Comput. Appl. IEEE, Maribor, pp 99-104

[10] Xia H, Tao M, Wang Y (2010) Sentiment text classification of customers reviews on the Web based on SVM. Proc - 2010 6th Int Conf Nat Comput ICNC 2010 7:3633-3637.

[11] Potrus MY, Ngah UK, Ahmed BS (2014) An evolutionary harmony search algorithm with dominant point detection for recognition-based segmentation of online Arabic text recognition. Ain Shams Eng J 5:1129-1139.

[12] Bestgen Y (2006) Improving Text Segmentation Using Latent Semantic Analysis: A Reanalysis of Choi ,. Assoc Comput Linguist 32:5-12.

[13] Sunayama W, Iyama A, Yachida M (2006) HTML text segmentation for Web page summarization by a key sentence extraction method. Syst Comput Japan 37:26-36.

[14] Xie L, Zeng J, Feng W (2008) Multi-Scale TextTiling for Automatic Story Segmentation in Chinese Broadcast News. In: 4th Asia Infomation Retr. Symp. Springer Berlin Heidelberg, Harbin, pp 345-355

[15] Zhu J, Zhu M, Wang H, Tsou BK (2009) Aspect-based sentence segmentation for sentiment summarization. In: Proceeding 1st Int. CIKM Work. Top. Anal. mass Opin. - TSA '09. ACM, Hong Kong, pp 65-72

[16] Xia Z, Suzhen W, Mingzhu X, Yixin Y (2009) Chinese text sentiment classification based on granule network. In: 2009 IEEE Int. Conf. Granul. Comput. GRC 2009. IEEE, Nanchang, pp 775778

[17] Mukund S, Srihari R, Peterson E (2010) An Information-Extraction System for Urdu-A Resource-Poor Language. ACM Trans Asian Lang Inf Process 9:1-43.

[18] Liu X, Zuo M, Chen L (2010) The application of text mining technology in monitoring the network education public sentiment. In: 2010 Int. Conf. Comput. Intell. Softw. Eng. IEEE, Wuhan, pp $1-4$

[19] Li N, Wu DD (2010) Using text mining and sentiment analysis for online forums hotspot detection and forecast. Decis Support Syst 48:354-368.

[20] Misra H, Yvon F, Cappé O, Jose J (2011) Text segmentation : A topic modeling perspective. 
Inf Process Manag 47:528-544.

[21] Fan J (2011) Text segmentation of consumer magazines in PDF format. Int Conf Doc Anal Recognition, ICDAR 794-798.

[22] 22. Ranaivo-Malançon B (2011) Building a rule-based Malay text segmentation tool. In: 2011 Int. Conf. Asian Lang. Process. IALP 2011. IEEE, Penang, pp 276-279

[23] Paliwal S, Pudi V (2012) Investigating Usage of Text Segmentation and Inter-passage Similarities. In: Mach. Learn. Data Min. Pattern Recognit. Springer Berlin Heidelberg, Berlin, pp 555-565

[24] P. D, Visweswariah K, Wiratunga N, Sani S (2012) Two-part segmentation of text documents. In: Proc. 21st ACM Int. Conf. Inf. Knowl. Manag. - CIKM '12. ACM New York, NY, USA (C2012, Maui, p 793

[25] Clausner C, Antonacopoulos A, Pletschacher S (2012) A robust hybrid approach for text line segmentation. In: 21st Int. Conf. pattern Recognit. IEEE, Tsukuba, pp 335-338

[26] Ye FY, Chen Y, Luo X, et al (2012) Research on topic segmentation of Chinese text based on lexical chain. In: 12th Int. Conf. Comput. Inf. Technol.IEEE, Chengdu, pp 1131-1136

[27] Myint N, Aung M, Maung SS (2013) Semantic Based Text Block Segmentation Using WordNet. Int J Comput Commun Eng 2:601-604.

[28] Chiru C, Teka A (2013) Sentiment-Based Text Segmentation. In: 2nd Int. Conf. Syst. Comput. Sci. IEEE, Villeneuve d'Ascq, France, pp 234-239

[29] Fragkou P (2013) Text Segmentation for Language Identification in Greek Forums. In: Proc. Adapt. Lang. Resour. Tools Closely Relat. Lang. Lang. Var. Elsevier B.V., Hissar, pp 23-29

[30] Lan Q, Li W, Liu W (2015) Chinese Text Sentiment Orientation Identification Based on Chinese-Characters. In: Fuzzy Syst. Knowl. Discov., 2015 12th Int. Conf. IEEE, Zhangjiajie, pp 663-668

[31] Alemi AA, Ginsparg P (2015) Text Segmentation based on Semantic Word Embeddings. In: KDD2015. ACM, Sydney, Australia, pp 1-10

[32] Liu SM, Chen J-H (2015) A multi-label classification based approach for sentiment classification. Expert Syst Appl 42:1083-1093.

[33] Liu W, Wang L (2016) How does Dictionary Size Influence Performance of Vietnamese Word Segmentation? In: Proc. Tenth Int. Conf. Lang. Resour. Eval. European Language Resources Association, Portorož, Slovenia, pp 1079-1083

[34] Logacheva V, Specia L (2016) Phrase-Level Segmentation and Labelling of Machine Translation Errors. In: Tenth Int. Conf. Lang. Resour. Eval. European Language Resources Association, Portorož, Slovenia, pp 2240-2245

[35] Homburg T, Chiarcos C (2016) Akkadian Word Segmentation. In: Proc. Tenth Int. Conf. Lang. Resour. Eval. European Language Resources Association, Portorož,Slovenia, pp 4067-4074 